UDC 622.625 .28

V.P. Franchuk, Dr. Sc. (Tech.), Prof., orcid.org/0000-0003-0808-6606,

K. A. Ziborov, Cand. Sc. (Tech.), Assoc. Prof., orcid.org/0000-0002-4828-3762,

V.V. Krivda, Cand. Sc. (Tech.), Assoc. Prof., orcid.org/0000-0002-8304-2016,

S. O. Fedoriachenko, Cand. Sc. (Tech.), Assoc. Prof. orcid.org/0000-0002-8512-3493
DOI: $10.29202 /$ nvngu/2018-2/7

National Mining University, Dnipro, Ukraine, e-mail: franchuk@nmu.org.ua

\title{
INFLUENCE OF THERMOPHYSICAL PROCESSES ON THE FRICTION PROPERTIES OF WHEEL - RAIL PAIR IN THE CONTACT AREA
}

Purpose. Determination of the regularities in the variation of the coupling parameters of the wheel-rail pair and the energy consumption accompanying them, taking into account the thermophysical processes in the contact zone in the transmission of friction motion for various interaction conditions.

Methodology. An analytical model for the interaction of a wheel and a rail on an elementary contact spot is developed in the presence of normal and tractive effort. A dependence that describes the change in the average temperature at the contact spot of the wheel-rail pair on the locomotive speed is obtained. The current value of the elasticity modulus of the contacting pair material is determined as a contact time function.

Findings. Based on theoretical studies of the parameters of vehicle motion along the railroad track, a mathematical model of the tractive force realization for nonstationary rectilinear motion is formulated. To determine the influence degree of the temperature change on the contact spot of the wheel-rail pair associated with the speed of the locomotive motion and the relative speed of the output links, the dependences for the coefficient characterizing the tractive power of the vehicle are obtained.

Originality. Taking into account the thermophysical processes that occur during the interaction of contacting bodies, analytical dependencies have been obtained to determine the traction capacity for different movement speeds and the relative speed of the wheel and rail movement for main and mine locomotives. The dependencies suggested take into account the change in the properties of the surface layers of the contacting pair.

Practical value. Knowledge of physics of the processes occurring in the contact zone of the wheel-rail pair will allow more accurately predicting the vehicles tractive properties, comparing possible options at the design stage and greatly accelerating the process of selecting the structural scheme. This will allow developing recommendations and proposals on modernization and improvement of existing vehicles.

Keywords: temperature, contact spot, modulus of elasticity, tractive capacity, vehicle

Introduction. Interaction of bodies with a moving contact point (for vehicles it is primarily the interaction of output links with the external environment, but also in the transfer of motion between links of mechanisms forming kinematic pairs) is the basis of physical processes associated with the movement of goods, as well as the rolling process, accompanied by grip and the traction or braking forces during the main working processes. The core of the adhesion process is the frictional interactions between these links and the external environment.

The existing problem of insufficient use of wheels frictional properties are unjustified energy losses, due to a decrease in its performance characteristics.

The rolling of locomotive wheels along rails, despite the seeming simplicity, is a complex dynamic process. The imperfection of the characteristics of the bandage and rail materials, the constant change in the motion conditions, influence of numerous random factors make it extremely difficult to analyze the rolling process and the cohesive forces acting at the same time. Therefore, the true picture of the emergence and realization of the cohesion force remains one of the main unresolved

(C) Franchuk V.P., Ziborov K.A., Krivda V.V., Fedoriachenko S. O., 2018 problems. In these conditions, the requirements for assessing the traction properties of locomotives, as well as increasing the longevity of friction pairs, increase.

Like any complex physical phenomenon, the process of cohesion of two contacting surfaces should be considered, abstracting from the layering, that can be excluded from consideration in the first approximation, complicating and refining the problems in the future by introducing new factors that affect the value of the frictional coefficient [1].

Thus, the process of contacting bodies interaction is very complex both in the physical and in the analytic terms. Therefore, there is no single approach to the study this process, which generates many analytical expressions for its description. This situation is caused by the fact that most researchers proceed from the positions of interaction of contacting surfaces, rather than real physical friction conditions with inherent elastic bodies and loading conditions on the contact surface.

Therefore, the task of predicting the properties of vehicles, taking into account the real conditions of frictional interaction on the surfaces of contacting elements, is integral when comparing possible options at the design stage and will accelerate the process of selecting the structural scheme, and will also develop recommenda- 
tions and proposals for implementing modernization and improvement of existing ones.

The purpose of the work is to determine the regularities in the variation of the coupling parameters of the wheel-rail pair of rail transport and the energy costs accompanying them, taking into account the thermophysical processes in the contact zone during the transmitting friction motion for various interaction conditions.

Presentation of the main research and explanation of scientific results. Coefficient of adhesion in traction calculations it is customary to call the ratio of traction force $Q_{x y}$ applied along the tangent to the contacting surface to the force of normal pressure $Q_{z}$ on this surface

$$
f=\frac{Q_{x y}}{Q_{z}} \leq \mu_{0},
$$

where $\mu_{0}$ is the coefficient of limiting friction.

Coefficient of adhesion depends on many factors. The most important of these include the appearance and condition of the surface of the contacting bodies, the presence or absence of lubricant (moisture or oil stains, colloidal substances, etc.), the surface temperature on the contact spot; the geometric and rheological characteristics of the contacting bodies; state of the material on the contact spot, the nature of the applied load. The processes carrying in the real contact area $\Phi$ (Fig. 1), are localized in tiny surface layer.

Until now, the main factors that were taken into account analyzing the friction pairs work were the permissible effort with mutual mechanical contact and the ability of the material to resist them. The increase in the normal force $Q_{z}$, corresponding to the factor of proportionality of the frictional coefficient (1), increases the transmitted tangential force $Q_{x y}$. However, this increase in the weight of the rail vehicle is limited by the permissible contact loads between wheel and rail and the maximum load on the rail at a given distance between the sleepers. As it was considered [2], the wear resistance depends on the composition of the friction pair material, but the structure of the material was not taken into account, moreover, the structure change during friction was ignored.

It is substantiated [3] that the contact of real solids is discrete and occurs in separate spots, where the materials friction releases heat during relative body sliding. In addition, a significant temperature increase is observed in the short-term contact interaction of bodies [6]. In

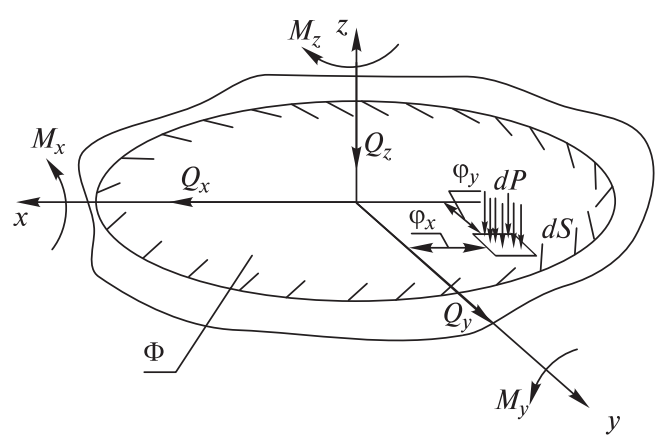

Fig. 1. External forces, acting in the contact surface this case, significant changes in the properties of materials in the surface layers that affect their physical and mechanical properties are possible.

Therefore, it can be assumed that the temperature in the transmission of tractive effort by the wheel along the rail is one of the important criteria in evaluating the frictional properties and wear of this pair, and depends both on the contact load (contact temperature) and the sliding speed (temperature at adhesion failure).

The increase in temperature significantly affects the mechanical characteristics of structural materials, such as creep and long-term strength. Creep is accompanied by stress relaxation - a non-arbitrary decrease in stress with constant deformation. The relaxation rate of the stress increases with temperature increasing. Temperature coefficient of linear expansion $\alpha=\frac{1}{r} \frac{d r}{d T}$ and temperature coefficient of elastic modulus $\eta=\frac{1}{E} \frac{d E}{d T}$ are connected by relation $\eta+\alpha \cdot m=0$ or $(\eta / \alpha)=-m=$ = const, where $r$ and $m-$ constants, that characterize the parameters of crystal cell [4].

Fig. 2 represents the relation, which describes temperature influence on dimensionless parameter of the existing elastic modulus relation to elastic modulus at normal temperature. The following description of such relation has been written in [4]

$$
E=E_{0} \exp \left[\alpha_{1}\left(1-\frac{T_{n}-T_{0}}{T_{n}-T}\right)\right],
$$

where $E_{0}$ is the elastic modulus at normal temperature $T_{0} ; T_{n}$ is the temperature of steel plasticity; $\alpha_{1}-$ coefficient of proportion.

As it follows, the increase in temperature the elastic modulus $E$ reduces and decreases the value of friction coefficient. Also increase in temperature leads to reduce in value of shear stress. The expression (5) [1] explains this fact.

While studying the wheel-rail contact, the temperature of the surfaces in the center of the contact spot plays significant role and can exceed the temperature of the

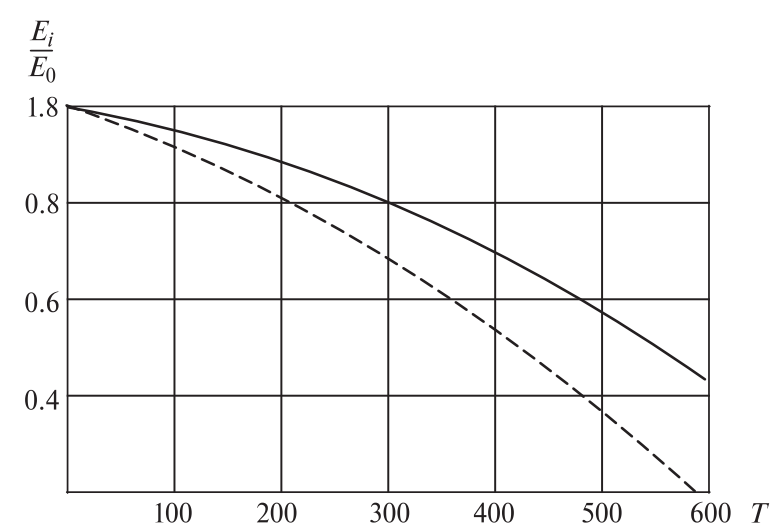

Fig. 2. Dependence of dimensionless elastic modulus on temperature:

- - stainless steel; --_-- - carbon steel 
environment by several hundred degrees [3]. At high temperatures, despite its short duration, the metal becomes softer, which leads to the detachment of its particles from the surface. The nominal hardness of the locomotive wheel set bandage of HB1 is less, than the rail HB2, so when analyzing the running process, a softer material, the bandage, is deformed. When cooled, torn particles, due to their small mass, receive a high hardness, and ultimately are an abrasive that forms a friction surface and creates the conditions for increasing the coefficient of friction, acting as a possible additional factor in the growth of tractive effort.

The analytical description of the contacting surfaces layers movement should be based on essentially nonlinear relations between the acting forces, deformations and relative slip of the material. These laws should characterize the unsteady state of the shroud and rail material under non-stationary operating conditions (especially when the grip is lost), and also taking into account the friction work.

The surface layers of the railhead and the shroud, due to the interaction of the rolling stock and the pivot, are more prone to plastic deformations than those lying behind them in depth. As a result, the surface layers acquire the greatest hardness. Fig. 3 shows the hardness of HB from the place of cross-section of the railhead and the tonnage traversed along the rail [5].

In the mining operational conditions, the surface layers of the railhead and bandage, being in continuous non-stationary frictional interaction, constantly react with the environment and substances that have appeared in the contact spot. At the same time, differences in their properties, polydisperse pollution, depending on the conditions of mine environment, as well as different oxide films are not capable to maintain their integrity in the complex combined (sliding-rolling) movement of the mine locomotive. In addition, to the distribution of organic contaminants on the friction surface, the temperature flares on the protrusions of the contacting bodies have a significant effect, since the structural-rheological, and hence frictional properties of these contam-
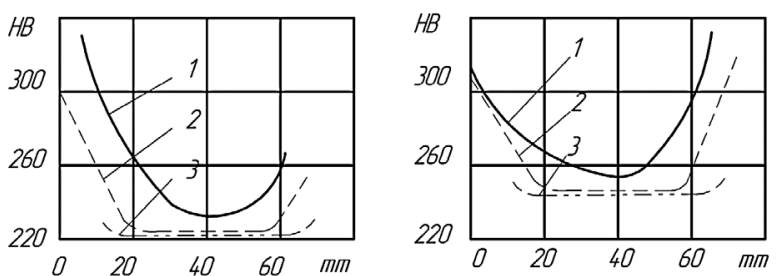

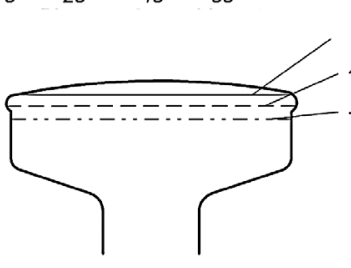

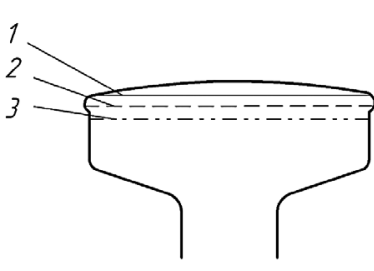

$b$
Fig. 3. Dependence of rail hardness on section:

$a$ - operating tonnage 210 mln.t.; $b$ - operating tonnage 770 mln.t; 1, 2, 3-rail section and corresponding relations inants depend on the amount of the liquid phase contained in them. From one hand, to apply the Derevyagin approach $R_{N}=\left(C \beta \cdot 12 \cdot \chi \cdot V \cdot R_{N N}^{\prime \prime}\right) /\left(\left(h_{0} \cdot \alpha\right)+3 \theta \times\right.$ $\left.\times R_{N}^{\prime \prime}\right) / 2 \cdot \alpha$ [12], it could be said about significant influence of the lift force, acting between moving wheel and rail with speed $V$ if the presence of surface contaminations with definite thickness, viscosity, influencing on tracktive (Fig. 4).

From the other hand, taking into account the real exploitation speed of mining locomotive, existing characteristics of mining contaminations, and that fact, that high temperature in the contacting zone can evaporate them cleaning the surface areas. However, the last does not influence on the tractive characteristics significantly.

As can be seen from Fig. 4 for really possible parameters per $1 \mathrm{~cm}$ of wheel and rail contact area, the magnitude of this force for a given value of the layer viscosity and the speed can be sufficient to detach the wheel from the rail and to transmit the friction mode from the boundary to the quasihydrodynamic in cases when viscosity $\eta=0.55, \eta=0.11$ ) [11]. This mode can be alternating, non-stable and lead to a sharp reduction in the adhesion of locomotive wheels to the rails. However, the increase in liquidity on rails contaminations $(\eta=0.0012)$ with increasing temperature in the zone of frictional contact (typical for mine conditions, failure adhesion) leads to a sharp decrease in unloading forces, increased plastic deformation, adhesion of contacting bodies and restoration of the adhesion of wheels to rails.

Therefore, to a greater extent in the phenomena while studying zone of frictional interaction between the wheel-rail pair for the operating conditions of mine locomotives, it is necessary to denote, that influence of thermophysical processes occurring on the surface of this pair precisely.

Let us consider in more detail the process of interaction when the wheel is rolled on a section of a rail. As noted by the authors of this work in earlier studies, contact will occur over a site of finite dimensions, which has the shape of an ellipse with a large and a minor semiaxis, respectively, $a$ and $b[1]$.

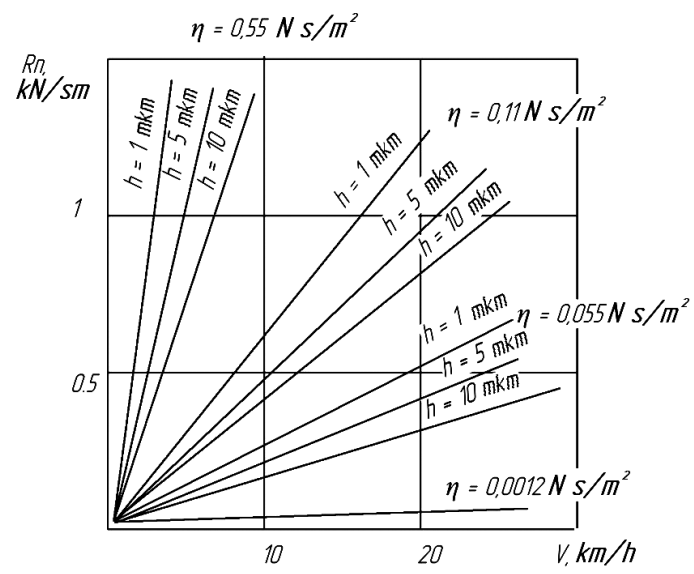

Fig. 4. Relations of the lifting forces $R_{n}$, acting between rolling wheel and rail with speed $V$ while existence of surface contaminations of different thickness $h$ and viscosity $\eta$ 
The body heating up on value $\Delta T$, than its relative elongation consists $\varepsilon=\Delta l / l$. Namely, dependence of elongation on temperature obeys the law $\varepsilon=\alpha_{0} \cdot \Delta T$. The opposite task is also possible: during immediate deformation, when the energy cannot get in time to dissipate, the body temperature increases on the value $\Delta T=\left(\varepsilon / \alpha_{0}\right)$. Taking into account the energy dissipation, relation will be transformed to following kind $\Delta T=e^{-k t} \cdot\left(\varepsilon / \alpha_{0}\right)$. Considering, that body stress $\sigma=E \cdot \varepsilon$, it could be written as

$$
\Delta T=e^{-k t} \frac{\sigma}{E \alpha_{0}},
$$

where $k$ is the coefficient of energy dissipation; $t$ is the time; $\sigma$ is the stress; $E$ is the modulus of elasticity; $\alpha_{0}$ is the coefficient of thermal expansion.

Maximal temperature within the contact area will be

$$
\Delta T=e^{-k t} \frac{1.5 Q\left(E_{1}+E_{2}\right)}{\pi a b E_{1} E_{2} \alpha_{0}} .
$$

Or, making transformations we will get

$$
\Delta T=e^{-k t} \frac{1.5 Q}{\pi a b E_{f r} \alpha_{0}}
$$

where $E_{f r}=\frac{E_{1} E_{2}}{E_{1}+E_{2}}$ is the reduced elasticity modulus of wheel-rail system.

Duration of the contact $t$ equals to interaction of the wheel with rail within the contact spot $t_{C}$, i.e. $t_{C}=\frac{2 a}{V_{1}}$, and average temperature (excluding the change in elasticity modulus) along this time will be

$$
\Delta T=\frac{1}{4} e^{-k t} \frac{1.5 Q}{\pi a b E_{f r} \alpha_{0}} \int_{-1}^{1} \sqrt{1-\xi_{x}^{2}} d \xi_{x} \int_{-1}^{1} \sqrt{1-\xi_{y}^{2}} d \xi_{y}
$$

Or, after integrating

$$
\Delta T=0.9255 e^{-k t} \frac{1.5 Q}{\pi a b E_{f r} \alpha_{0}} .
$$

In Fig. 5 the relation, describing the change in average temperature on the wheel-rail contact spot in dependence on locomotive speed is given. As it is shown, the increase in locomotive speed causes the linear increase of temperature in the contact area, which characteristic is also linear up to a $10-15 \mathrm{~m} / \mathrm{s}$ speed. When the speed becomes around 40-60 m/s the curve flattens, namely the temperature in the contact area is almost constant. kind

Let us transform the equation (2) up to the following

$$
E=E_{0} \exp \left[\alpha_{1} \frac{\Delta \grave{O}}{T_{N}-T_{0}-\Delta T}\right]
$$

where $\Delta T$ is the excess of the temperature in the contact spot over the normal $\left(T_{0}\right) ; E_{0}$ is the reduced modulus of elasticity while initiate temperature $\left(20^{\circ} \mathrm{C}\right)$.

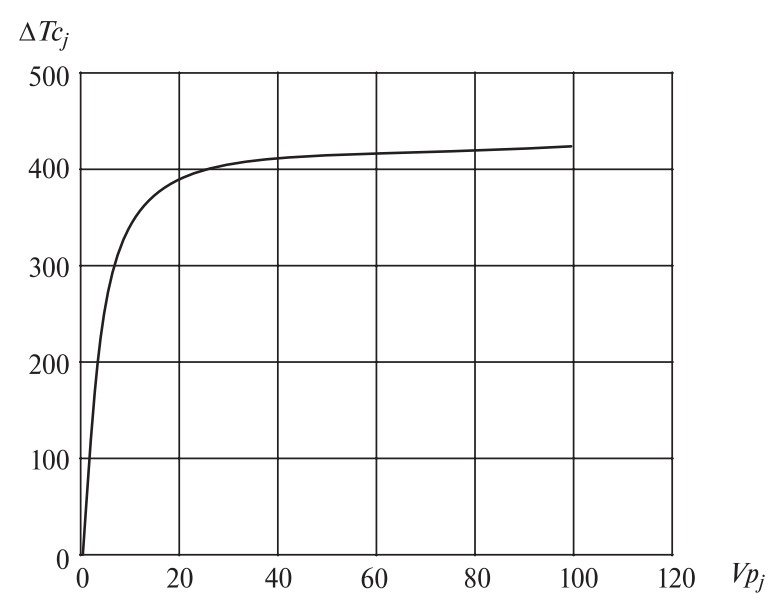

Fig. 5. The value of average temperature in the contact spot in dependence on the speed [9]

As it follows from the materials [1, 4], the elasticity modulus influences on coefficients $\alpha$ and $l$, and the decrease in elasticity modulus in direct proportion influences on coefficient $\alpha$ decrease and inversely on $l$ change [13]. Taking into account, that initial modulus is obtain experimentally at given speed, it could be considered as etalon, and we can include correction factor of temperature influence on elasticity modulus.

Thus, elasticity modulus in dependence on vehicle speed will be

$$
E=E_{0} \exp \left\{\frac{-\alpha_{1} \frac{0.9255 Q}{\pi a b \alpha_{T} E_{0}} \exp \left(-k \frac{a}{V}\right)}{T_{N}-T_{0}-\frac{0.9255 Q}{\pi a b \alpha_{T} E_{0}} \exp \left(-k \frac{a}{V}\right)}\right\} .
$$

In Fig. 6 there is a graph of the reduced wheel-rail pair elasticity modulus in dependence on the locomotive speed. As it can be seen from the graph, with increasing locomotive motion speed, the modulus of elasticity first decreases quite intensively, due to the increase in temperature of contact zone. At a speed of $18-20 \mathrm{~m} / \mathrm{s}$ the curve becomes more dense, because the temperature in the contact zone is stabilized.

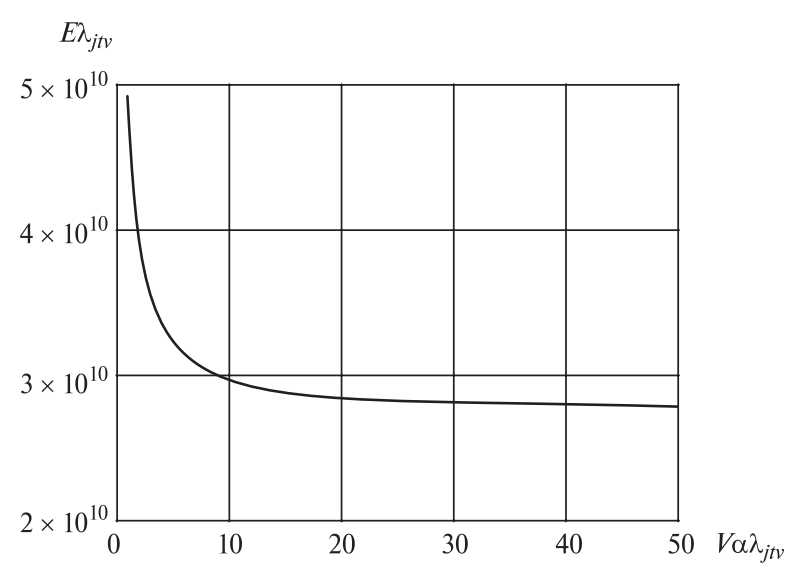

Fig. 6. Dependence of reduced elasticity modulus on vehicle speed 
Then, elasticity modulus during etalon locomotive speed $V_{E}$, that has been obtained during experiment [7] will be

$$
E=E_{0} \exp \left\{\frac{-\alpha_{1} \frac{0.9255 Q}{\pi a b \alpha_{T} E_{0}} \exp \left(-k \frac{a}{V_{E}}\right)}{T_{N}-T_{0}-\frac{0.9255 Q}{\pi a b \alpha_{T} E_{0}} \exp \left(-k \frac{a}{V_{E}}\right)}\right\} .
$$

Correction factors $\alpha, \beta, d, l$ for specific experimentally obtained motion conditions could be also concerned as the etalon. In particular, as the etalon the speed $V_{E}=10 \mathrm{~m} / \mathrm{s}$ is taken for mainline locomotives and $V_{E}=4 \mathrm{~m} / \mathrm{s}-$ for mining one [10]. Taking into account, that coefficient $\alpha$ is in direct proportion and coefficient $l$ is inverse proportionality on reduced elasticity modulus, then correction factor is

$$
K_{E}=\frac{E}{E_{E}} ; \quad \alpha=\alpha^{\prime} K_{E} ; \quad \lambda=\frac{\lambda_{1}}{K_{E}} .
$$

Substituting the corresponding values of $\alpha$ and $\lambda$ to expression for $\chi$ we will get the relation of the wheel tracktive effort in dependence on relative motion speed $æ$ during different locomotive velocities $V$

$$
\chi=\frac{k}{\delta k^{2} V+\beta k+\lambda} .
$$

In Fig. 7 the relation of the tractive effort of the body with moving contact point during different motion speed accounting temperature changes within contact spot is presented.

To define the influence degree on the wheel-rail contact spot connected with locomotive speed let us compare obtained relations, that characterize tractive effort of the specific vehicle during different speed (Fig. 8) [8].

As we can see, the curve reflects temperature effect on the contact spot of the wheel-rail pair, connected with the change in the speed of the vehicle, passes somewhat below the curve without taking temperature into account. The fact is that some temperature has already been taken into account when determining the coefficients $\delta, \beta, \lambda$. And, in principle, the temperature in a given range of variation (Fig. 5) has no significant effect on the parameters of locomotive movement, including because it is partially taken into account when determining the empirically found coefficients $[14,15]$. At the same time, to predict the traction ability of the vehicle, its recording will improve the accuracy of the final result.

Thus, the traction depends on the normal load at the contact point $Q_{z}$, the speed of relative movement of the contacting bodies $æ$, the absolute speed of the locomotive $V$, the elastoplastic properties and the shape of the surface of the contacting bodies determined by the coefficients $\beta, \delta, \lambda$. The coefficient $\mu_{0}$ depends on the material of the contacting bodies and is defined as the classical coefficient of friction of rest. As for the coefficient $\alpha^{\prime}$, it determines the state of the surface of the contacting bodies (presence of lubricant, pollutants, etc.). Here we

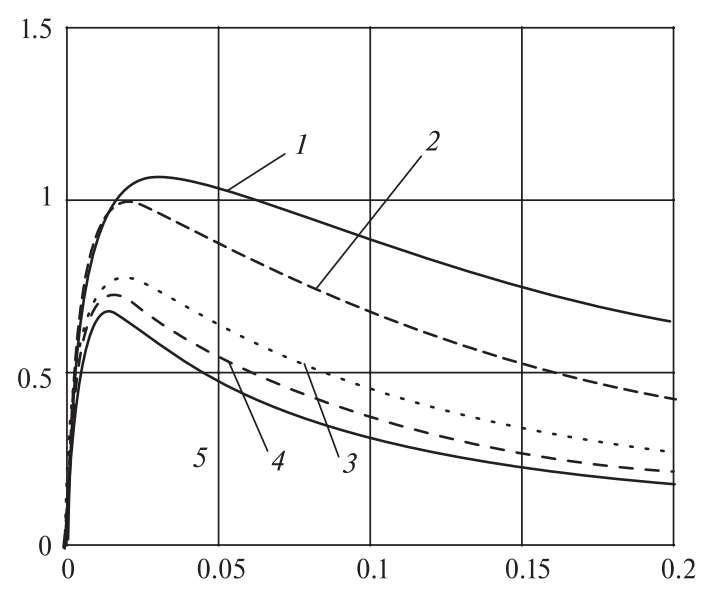

Fig. 7. Values of the coefficient of locomotive tracktive effort accounting temperature within contact spot:

$1-V=5 \mathrm{~m} / \mathrm{s} ; 2-V=10 \mathrm{~m} / \mathrm{s} ; 3-V=15 \mathrm{~m} / \mathrm{s} ; 4-V=$ $=20 \mathrm{~m} / \mathrm{s} ; 5-V=25 \mathrm{~m} / \mathrm{s}$

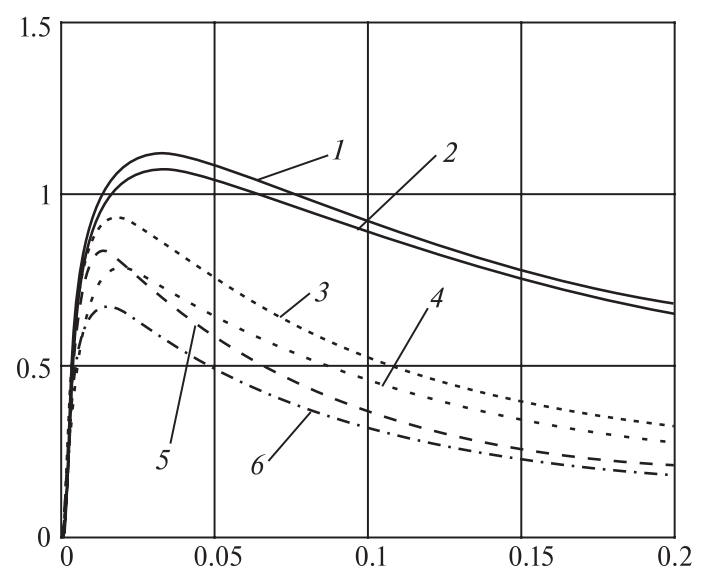

Fig. 8. Changes in the coefficient characterizing the traction capacity of the locomotive: without taking into account the temperature in the contact zone:

$1-V=5 \mathrm{~m} / \mathrm{s} ; 3-15 \mathrm{~m} / \mathrm{s} ; 5-25 \mathrm{~m} / \mathrm{s}$; considering temperature: $2-5 \mathrm{~m} / \mathrm{s} ; 4-15 \mathrm{~m} / \mathrm{s} ; 6-25 \mathrm{~m} / \mathrm{s}$

can also include corrections that have a real coefficient of friction, in contrast to the friction coefficient, and are introduced into the experiment by the actual motion regime of the contacting bodies.

Conclusions. In work on the basis of theoretical studies of the parameters of the vehicle motion along the railroad track, a mathematical model of the interaction of the wheel and rail on the elementary section of contact is formulated in the presence of normal and tractive effort. Using the analytical model of obtaining the dependence, which describes the change in the average temperature on the contact spot of the wheel-rail pair on the speed of the locomotive. The current value of the modulus of elasticity of the material of the contacting pair is determined as a function of the contact time.

The obtained dependence of the traction ability of the rail vehicle on the speed of the contacting bodies (movement of the wheel along the rail) shows that the value of the coefficient of adhesion for both the absolute and relative velocity decreases, which corresponds to the 
results of experimental studies [7]. Further growth leads to a breakdown of adhesion (boxing), an increase in temperature in the contact zone, which also contributes to a reduction in the traction properties of the locomotive.

\section{References.}

1. Franchuk, V. P., Ziborov, K.A., Fedoriachenko, S. A. and Krivda, V. V., 2017. On Wheel Rolling Allong the Rail Regime with Longitudinal Load. Naukovyi Visnyk Natsionalnoho Hirnychoho Universytetu, 3, pp. 75-80.

2. Lewis, R., Magel, E., Wang, W.-J., Olofsson, U., Lewis, S., Slatter, T. and Beagles, A., 2017. Towards a standard approach for the wear testing of wheel and rail materials. Proceedings of the Institution of Mechanical Engineers, Part F: Journal of Rail and Rapid Transit [ejournal], 231(7), pp. 760-774. DOI: 10.1177/ 0954409717700531.

3. Zabolotny, K. and Panchenko, E., 2010. Definition of rating loading in spires of multilayer winding of rubberrope cable. New Techniques and Technologies in Mining: School of Underground Mining 2010. CRC Press/Balkema, pp. 223-229.

4. Aditya Kadian, Sampann Arora, Akshath Sharma, Girish M. Joshi, Mayank Pandey, Anji Polu Reddy, Joshi, M. J. and Thomas, P., 2016. Improved dielectric constant of thermoplastic blend as a function of alumina loading. Measurement, 90, pp. 461-467.

5. Semrad, K., Cernan, J. and Draganova, K., 2016. Rolling Contact Fatigue Life Evaluation Using Weibull Distribution. Mechanics, Materials Science \& Engineering, 3(1), pp. 28-34. ISSN: 2412-5954.

6. Ahmed Abdelmoamen Khalil, 2017. Negative Impacts on Railway Embankments Exposed to WindBlown Sand and Optimizing the Economic Height. $\mathrm{Me}$ chanics, Materials Science \& Engineering [e-journal], 10. DOI: seo4u.link/10.2412/mmse.39.59.615.

7. Protsiv, V. V. and Monya, A. G., 2003. Experimental determination of characteristics of clutch of mine locomotive under the braking conditions, Metallurgicheskaya i Gornorudnaya Promyshlennost [online], 2, pp. 9597. Available at: <https://www.researchgate.net/publication/293546988_Experimental_determination_of characteristics_of_clutch_of_mine_locomotive_un-

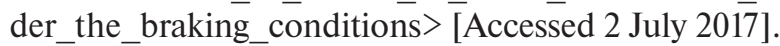

8. Bajelan, A. and Akbarimajd, A., 2016. A new mechanism for passive dynamic object manipulation along a curved path. Journal for Control, Measurement, Electronics, Computing and Communications, 57(1), pp. 188-200. 9. Ziborov, K.A., Protsiv, V. V., Fedoriachenko, S. O. and Verner, I. V., 2016. On Influence Of Design Parameters Of Mining Rail Transport On Safety Indicators. Mechanics, Materials Science \& Engineering, 2(1), pp. 63-70.

10. Kyrychenko, Y., Samusia, V. and Kyrychenko, V., 2012. Software development for the automatic control system of deep-water hydrohoist. In: Geomechanical Processes During Underground Mining - Proceedings of the School of Underground Mining 2012 [online], pp. 81-86. Available at: <http://antosoft.net/ebooks/ 75678-geomechanical-processes-during-undergroundmining-school-of-underground-mining-2012.html> [Accessed 24 July 2017].
11. Ilin, S. R., Samusia, V. I., Ilina, I. S. and Ilina, S. S., 2016. Influence of dynamic processes in mine hoists on safety exploitation of shafts with broken geometry. Naukovyi Visnyk Natsionalnoho Hirnychoho Universytetu, 3, pp. 42-47.

12. Matsyuk, I. and Shlyahov, E., 2015. The research of plane link complexstructure mechanisms by vector algebra methods, Eastern European Journal of Enterprise Technologies, 3(7), pp. 34-38.

13. Kravets, V. V. and Kravets, T. V., 2009. Kinetic energy of an asymmetric rigid body moving around a fixed point: Invariant representation in terms of quaternion matrices. International Applied Mechanics [e-journal], 45(12), pp. 1374-1379. DOI: 10.1007/s10778-010-0275-7.

14. Kolosov, D., Dolgov, O. and Kolosov, A., 2013. The stress-strain state of the belt on a drum under compression by flat plates. In: Annual Scientific-Technical Colletion - Mining of Mineral Deposits, pp. 351-355.

15. Samusia, V. I., Oksen, Y. I. and Radiuk, M. V., 2013. Heat pumps for mine water waste heat recovery. Annual collection of scientific-technical papers "Mining of mineral deposits”, pp. 153-157. DOI: 10.1201/b16354-27.

\section{Вплив теплофізичних процесів на фрикційні властивості пари ,колесо - рейка“ в зоні контакту

\author{
В. П. Франчук, К. А. Зіборов, В. В. Крівда, \\ С. О. Федоряченко
}

Державний вищий навчальний заклад „Національний гірничий університет“, м. Дніпро, Україна, e-mail: franchuk@nmu.org.ua

Мета. Визначення закономірностей зміни параметрів зчеплення пар „колесо - рейка“ рейкового транспорту й супутніх їм енергетичних витрат з урахуванням теплофізичних процесів у зоні контакту при передачі руху тертям для різних умов взаємодії.

Методика. Розроблена аналітична модель взаємодії колеса та рейки на елементарній ділянці контакту за наявності нормальної й тягової сили. Отримана залежність, що описує зміну середньої температури в зоні контакту пари „колесо - рейка“ від зміни сили тяги локомотиву. Визначене поточне значення модуля пружності матеріалу контактуючої пари залежно від часу контакту.

Результати. На основі теоретичних досліджень параметрів руху транспортного засобу по рейковому шляху формулюється математична модель реалізації тягової сили при нестаціонарному прямолінійному русі. Для визначення ступеню впливу зміни температури на плямі контакту пари „колесо рейка“, пов'язаного зі швидкістю руху двигуна й відносною швидкістю вихідних ланок, отримані залежності коефіцієнта, що характеризує тягову здатність транспортного засобу.

Наукова новизна. 3 урахуванням теплофізичних процесів, що виникають при взаємодії контактуючих тіл, отримані аналітичні залежності для визначення тягової здатності при різних швидкостях руху екіпажної частини й відносної швидкості руху 
колеса та рейки для магістральних і шахтних локомотивів. Запропоновані залежності враховують зміни властивостей поверхневих шарів контактуючої пари.

Практична значимість. Знання фізики процесів, що відбуваються в зоні контакту пари „колесо рейка“, дозволить більш точно прогнозувати тягові властивості транспортних засобів, провести порівняння можливих варіантів на стадії їх проектування та значною мірою прискорити процес вибору структурної схеми. Це дозволить розробити рекомендації й пропозиції щодо модернізації та вдосконалення вже існуючих транспортних засобів.

Ключові слова: температура, зона контакту, модуль пружності, тягова здатність, транспортний засіб

\section{Влияние теплофизических процессов на фрикционные свойства пары „колесо-рельс“" в зоне контакта}

\section{В. П. Франчук, К.А. Зиборов, В. В. Кривда,} С. А. Федоряченко

Государственное высшее учебное заведение „Национальный горный университет“, г. Днепр, Украина, e-mail: franchuk@nmu.org.ua

Цель. Определение закономерностей изменения параметров сцепления пары „колесо - рельс“ рельсового транспорта и сопутствующих им энергетических затрат с учетом теплофизических процессов в зоне контакта при передаче движения трением для различных условий взаимодействия.

Методика. Разработана аналитическая модель взаимодействия колеса и рельса на элементарном участке контакта при наличии нормального и тягового усилия. Получена зависимость, которая описывает изменение усредненной температуры на пятне контакта пары „колесо-рельс“ от скорости движения локомотива. Определено текущее значе- ние модуля упругости материала контактирующей пары в зависимости от времени контакта.

Результаты. На основе теоретических исследований параметров движения транспортного средства по рельсовому пути сформулирована математическая модель реализации тягового усилия при нестационарном прямолинейном движении. Для определения степени влияния изменения температуры на пятне контакта пары „колесо - рельс“, связанной со скоростью движения локомотива и относительной скоростью выходных звеньев, получены зависимости для коэффициента, характеризующего тяговую способность транспортного средства.

Научная новизна. С учетом теплофизических процессов, происходящих при взаимодействии контактирующих тел, получены аналитические зависимости для определения тяговой способности при различных скоростях движения экипажной части и относительной скорости движения колеса и рельса для магистральных и шахтных локомотивов. Предложенные зависимости учитывают изменения свойств поверхностных слоев контактирующей пары.

Практическая значимость. Знание физики процессов, происходящих в зоне контакта пары „колесо-рельс“, позволит более точно прогнозировать тяговые свойства транспортных средств, выполнять сравнение возможных вариантов на стадии их проектирования и в значительной степени ускорит процесс выбора структурной схемы. Это позволит разработать рекомендации и предложения по модернизации и совершенствованию уже существующих транспортных средств.

Ключевые слова: температура, пятно контакта, модуль упругости, тяговая способность, транспортное средство

Рекомендовано до публікації докт. техн. наук О.М.Коптовцем. Дата надходження рукопису 13.01.17. 